\title{
Meiotic studies in Largus rufipennis (Castelnau) (Largidae, Heteroptera): frequency and behaviour of ring bivalents, univalents and $B$ chromosomes
}

\author{
L. M. MOLA \& A. G. PAPESCHI* \\ Laboratorio de Genética, Depto. de Ciencias Biológicas, FCEN, UBA. Int. Güiraldes y C. Norte, 1428, Buenos Aires, \\ Argentina. *Fellow of the Argentine Research Council (CONICET)
}

\begin{abstract}
Cytogenetic analysis of an Argentine population of Largus rufipennis has revealed the presence of autosomal univalents and a supernumerary chromosome. All individuals present univalents at a variable frequency $(0.31-21.83$ per cent $)$, and half of them carry a $B$ chromosome at low frequency. Both the B chromosome and univalents divide equationally at anaphase I and reductionally at the second division. The present population is very heterogeneous with respect to chiasma frequency and distribution: desynapsis is responsible for the appearance of univalents, while the presence of the B chromosome is associated with an increase in chiasma frequency. However, two individuals that lack the supernumerary chromosome show a strikingly high chiasma frequency. This variation in chiasma frequency should be the result of the interaction between genes controlling chiasmata and the environmental conditions (both internal and external) together with the genetic background of each individual.
\end{abstract}

Keywords: B chromosome, chiasma frequency, holokinetic chromosomes, ring bivalents, univalents.

\section{Introduction}

Although holokinetic chromosomes show unique behaviour during mitosis, they behave differently during meiosis according to the group of animals in which they are present (White, 1973). In Heteroptera, particularly, kinetic activity is restricted during meiosis to one telomeric region, but meiotic behaviour is slightly different depending on whether we are dealing with autosomal bivalents, sex chromosomes, $\mathrm{m}$ chromosomes or autosomal univalents. As a rule, autosomal bivalents have only one chiasma while sex and $\mathrm{m}$ chromosomes are always achiasmatic (Ueshima, 1979; Manna, 1984; Papeschi \& Mola, 1990).

From a cytogenetic point of view Largidae is an interesting family of Heteroptera because of the low diploid chromosome number of its species, and the large chromosome size in most of them. The six species of the subfamily Larginae which have been studied to date lack $\mathrm{m}$ chromosomes and have an $\mathrm{XO} / \mathrm{XX}$ sex chromosome mechanism; the number of autosomes, however, varies between 10 and 14 (Wilson, 1909; Piza, 1946, 1953; Banerjee, 1959; Vidal \& Lacau,
1985). All the studied species that belong to the other subfamily (Physopeltinae) possess 12 autosomes plus two $\mathrm{m}$ chromosomes, but different sex chromosome mechanisms (XO or $\mathrm{X}_{1} \mathrm{X}_{2} \mathrm{Y}, \mathrm{O}^{\prime}$ ) (Ray-Chaudhuri \& Manna, 1955; Ueshima, 1979; Manna et al., 1985).

In the present work the meiotic chromosome behaviour in an Argentine population of Largus rufipennis (Castelnau) is described and the origin and genetic consequences of the univalents and the $\mathrm{B}$ chromosome observed are discussed. This species has been previously studied by Piza (1946) as Euryophthalmus rufipennis, but in the population of San Pablo (Brazil) that he analysed neither univalents nor a supernumerary chromosome were found. The meiotic configurations, although already described by Piza (1946), are here interpreted according to the holokinetic nature of heteropteran chromosomes.

\section{Materials and methods}

Sixteen adult males of $L$. rufipennis (Castelnau) from Santo Tomé (Corrientes Province, Argentina) were fixed in the field in 3:1 ethanol:glacial acetic acid and 
kept at $4^{\circ} \mathrm{C}$. Afterwards, gonads were dissected free and kept in 70 per cent ethanol at $4^{\circ} \mathrm{C}$. Slides were prepared by the squash-technique in 2 per cent ironpropionic haematoxylin.

\section{Results}

\section{Chromosome complement and male meiosis}

The male chromosome complement is $2 n=12+\mathrm{XO}$ with three medium-sized pairs of autosomes, one pair larger and two smaller (Fig. 1a,i). From early prophase the $\mathrm{X}$ chromosome is positively heteropycnotic and lies at the periphery of the nucleus (Fig. $1 \mathrm{c}, \mathrm{d}$ ); at pachytene the association of the $\mathrm{X}$ and an autosomal bivalent with the nucleolus is apparent (Fig. 1e). At diakinesis the $\mathrm{X}$ is isopycnotic and the autosomal bivalents show one or two chiasmata in terminal positions (Fig. 1f-h); at this stage from one to four ring-shaped bivalents are observed. At both metaphase plates the $\mathrm{X}$ chromosome lies outside the ring of autosomes (Fig. $1 \mathrm{i}, \mathrm{j}, \mathrm{l})$. At metaphase I ring bivalents are generally placed a little apart from rod bivalents; in some metaphase plates $\mathrm{V}$-shaped bivalents with the angle on the

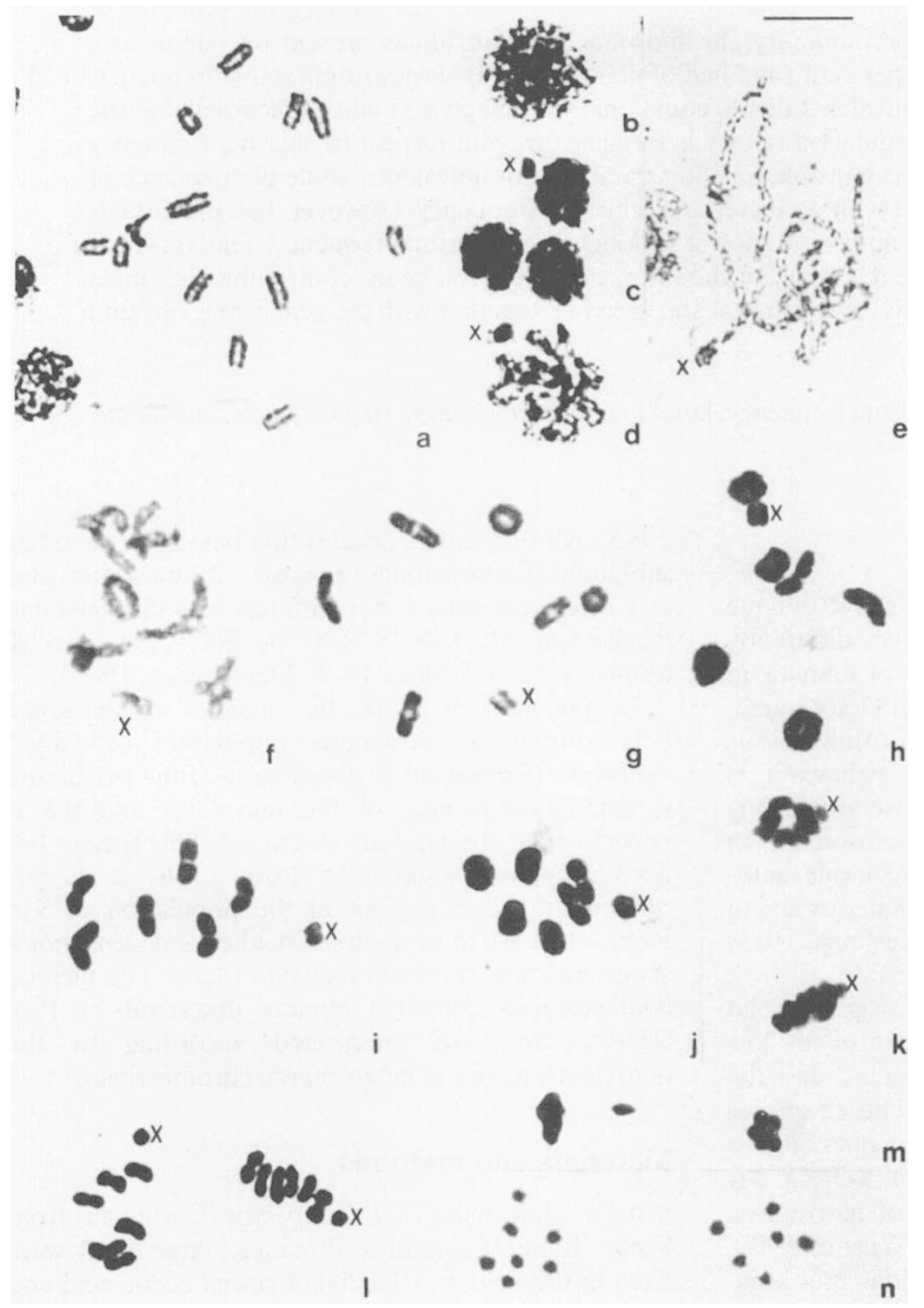

Fig. 1 Normal meiosis in L. rufipennis (Heteroptera). (a) Mitotic prophase. (b) Leptotene-zygotene. (c) Early pachytene. (d-e) Pachytene. (f) Diplotene. (g) Diakinesis with two ring bivalents. (h) Diakinesis with four ring bivalents. (i) Metaphase I with one V-shaped bivalent. (j) Metaphase I with four ring bivalents. (k) Telophase I. (l) Metaphase II. (m) Anaphase II. (n) Telophase II. Bar represents $10 \mu \mathrm{m}$. 
equatorial plane are observed (Fig. 1i; see also Fig. 2e, Fig. 4d). The $X$ chromosome divides equationally and synchronously with autosomal bivalents at anaphase I (Fig. 1k) and at the second anaphase it divides reductionally, lagging behind the autosomes (Fig. $1 \mathrm{~m}$ ). This yields telophase II nuclei with seven and six chromosomes $(6 \mathrm{~A}+\mathrm{X}, 6 \mathrm{~A})$ (Fig. 1n). As is usual in Heteroptera, autosomes arrange themselves in a circle at both metaphase plates; however, this arrangement is not always apparent owing to the low diploid number.

\section{Autosomal univalents}

All the specimens show cells with two and sometimes four univalents (Fig. 2a-e) (Table 1). The percentage of cells with univalents varies among individuals, and it can be low (0.31-1.77 per cent), medium (4.09-5.69 per cent) or high (11.06 and 21.83 per cent) (Fig. 3). In the individuals with a high frequency of univalents, although medium-sized chromosomes cannot be unequivocally identified, the presence of large, medium (Fig. 2b) and small-sized univalents (Fig. 2c,d) suggests that all autosomes can be affected.

Although early meiotic stages are in general difficult to analyse, the observed late pachytene cells did not reveal either unpaired chromosomes or unpaired chromosome segments. At diplotene, univalents are detected lying far apart (Fig. 2a), and they continue separated until late prophase (Fig. $2 \mathrm{~b}-\mathrm{d}$ ). At metaphase I the two univalents lie at the centre of the ring of autosomal bivalents (Fig. 2e), and divide equationally at anaphase I. At metaphase II they associate in a pseudobivalent (Fig. 2f,g) which generally lies in the

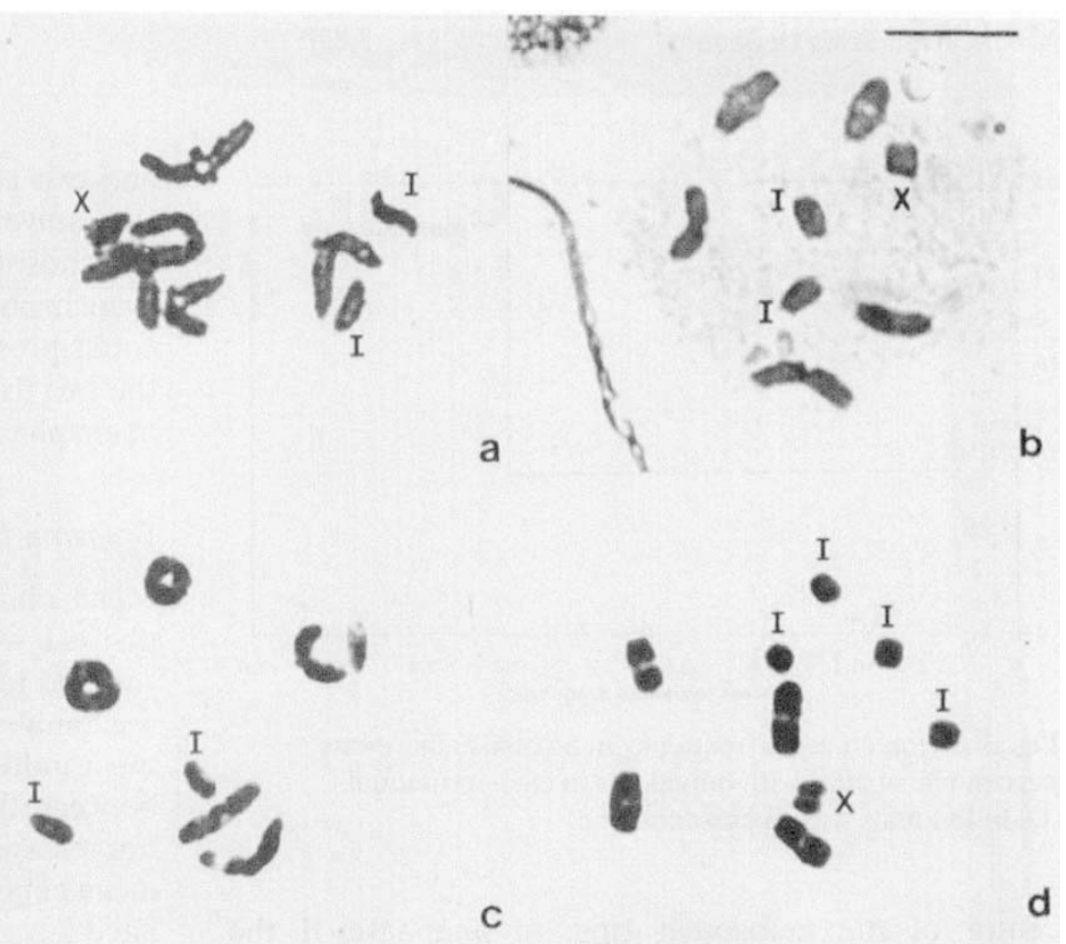

Fig. 2 Normal meiotic behaviour of univalents of $L$. rufipennis (Heteroptera). (a) Diplotene with two univalents. (b) Diakinesis with two medium-sized univalents. (c) Diakinesis with two univalents of small size and two ring bivalents. (d) Diakinesis with four small univalents. (e) Metaphase I with two univalents in the centre of the autosomal ring. (f-g) Metaphase II with univalents associated in a pseudobivalent (arrow). Bar represents $10 \mu \mathrm{m}$.

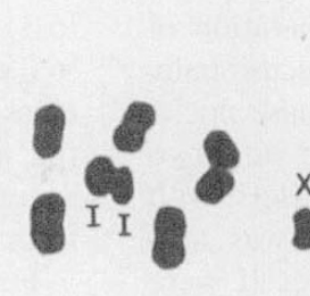

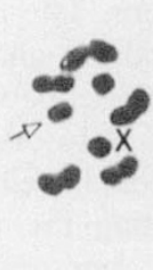

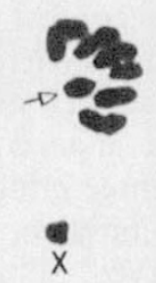

e f 
Table 1 Number of cells with univalents and mean chiasma frequency at diakinesis-metaphase $\mathrm{I}^{*}$

\begin{tabular}{rlllll}
\hline $\begin{array}{l}\text { Individual } \\
\text { number }\end{array}$ & $\begin{array}{l}\dot{\mathrm{X}}_{\text {total }} \\
\text { (number of cells) }\end{array}$ & $\overline{\mathrm{X}}_{\text {6II }}$ & $\begin{array}{l}\dot{\mathrm{X}}_{\text {5II }} \\
\text { (number of cells) }\end{array}$ & $\begin{array}{l}\dot{\mathrm{X}}_{4 \mathrm{II}} \\
\text { (number of cells) }\end{array}$ & $\begin{array}{l}\text { Cells } \\
\text { with I }(\%)\end{array}$ \\
\hline 14 & $7.46(319)$ & 7.47 & $5.00(1)$ & - & 0.31 \\
5 & $7.69(232)$ & 7.69 & $8.00(1)$ & - & 0.43 \\
4 & $6.24(241)$ & 6.25 & - & $4.0(1)$ & 0.41 \\
9 & $6.16(302)$ & 6.17 & $5.00(2)$ & - & 0.66 \\
7 & $6.39(374)$ & 6.40 & $5.33(3)$ & - & 0.80 \\
16 & $6.37(251)$ & 6.38 & $5.00(2)$ & - & 0.80 \\
6 & $6.28(254)$ & 6.28 & $5.67(3)$ & $4.0(1)$ & 1.18 \\
8 & $6.13(320)$ & 6.15 & $5.25(4)$ & - & 1.46 \\
13 & $6.20(205)$ & 6.23 & $5.00(2)$ & - & 1.77 \\
10 & $6.26(226)$ & 6.27 & $5.25(4)$ & - & 4.77 \\
3 & $6.54(338)$ & 6.56 & $5.60(5)$ & $4.0(1)$ & 4.09 \\
11 & $6.22(220)$ & 6.24 & $5.67(9)$ & - & 5.69 \\
12 & $6.27(266)$ & 6.31 & $5.36(11)$ & $4.0(4)$ & 11.06 \\
2 & $6.11(281)$ & 6.18 & $5.07(15)$ & & 21.83 \\
1 & $6.50(226)$ & 6.60 & $5.72(25)$ & & \\
15 & $6.13(197)$ & 6.35 & $5.49(39)$ & & - \\
\hline
\end{tabular}

${ }^{*}$ Cells with $\mathrm{B}$ chromosome are not included.

$\mathrm{X}=$ mean chiasma frequency.

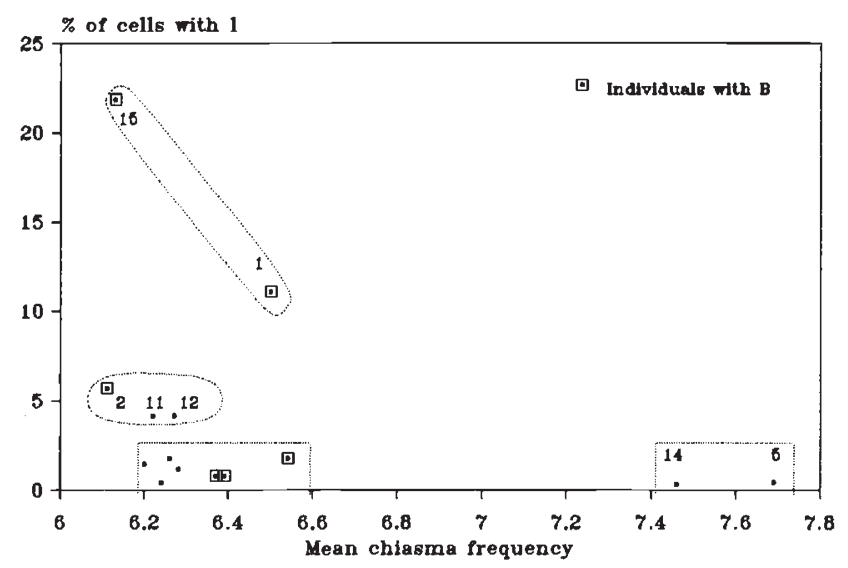

Fig. 3 Mean chiasma frequency in normal cells versus percentage of cells with univalents in each individual. (匹) Individuals with B chromosome.

centre of the autosomal ring; at anaphase II the pseudobivalent divides reductionally.

The behaviour of the univalents is highly regular, with very few exceptions. The delayed separation of the univalent chromatids at anaphase I occasionally produces chromatin bridges between telophase nuclei (three anomalous cells were observed with one, two and three bridges); a double cell at metaphase II with one univalent connecting the two nuclei was also observed. Some other abnormal metaphases II were observed in which the univalents do not associate in a pseudobivalent but lie side-by-side, or far apart (three and two cells out of 846, respectively); in these cases the univalents behave at anaphase II like the $\mathrm{X}$ chromosome, lagging behind the autosomes. The asynchronous division of the univalents at anaphase I could prevent cytokinesis, leading to the formation of the two tripolar and three tetrapolar spindles observed at anaphase II.

\section{Chiasma frequency}

Mean chiasma frequency at diakinesis and at metaphase I was calculated in each individual and a chisquared test was performed in all of them to compare the number of chiasmata at both meiotic stages. In most individuals the difference was not significant $(P$ between 0.06 and 0.89 ), indicating that chiasmata do not release between these meiotic stages. Then, a single mean chiasma frequency per individual could be calculated.

Differences were highly significant in individuals 8 and 9. As mean chiasma frequency at metaphase I (6.31 and 6.22, respectively) is higher than at diakinesis (6.08 in both), and because it is not possible that new chiasmata appear between diakinesis and metaphase I, the most plausible explanation for this difference is sampling error. So, in these individuals a single chiasma frequency could not be calculated.

Four groups of individuals are readily distinguished when the percentage of cells with univalents is plotted against mean chiasma frequency (Fig. 3). Most individ- 
uals show a mean chiasma frequency between 6.11 and 6.54. However, they fall into different categories according to the percentage of cells with univalents: low (seven individuals), medium (three individuals) or high (two individuals). The fourth group, composed of individuals 5 and 14 , is remarkable as chiasma frequency is very high (7.46 and 7.69); despite these high values a few cells with univalents were also encountered (Table 1). It must be pointed out that cells carrying the $\mathrm{B}$ chromosome were not included in this analysis.

In each individual, cells with two univalents have a mean chiasma frequency that is only one chiasma lower than cells with six bivalents (Table 1). This implies that, in those individuals in which cells with two or more ring bivalents are frequently observed, cells with univalents together with ring bivalents are also encountered.

\section{Chiasma distribution}

To ascertain whether the presence of univalents in the specimens of $L$. rufipennis was the result of random distribution of chiasmata, the equations proposed by Jackson $(1982,1984)$ for the random and non-random models of chiasma distribution (see discussion) were applied to each individual.
All individuals have been analysed by means of a goodness of fit test; to exemplify this, the results obtained in some individuals belonging to the four different groups mentioned previously are given in Table 2. None of the individuals fit the random distribution of chiasmata. In those individuals with low and medium frequency of univalents, chiasmata are distributed in a non-random fashion, while the specimens with a high percentage of univalents do not fit either of the two models.

\section{B chromosome}

A small supernumerary chromosome is detected in half of the individuals (Fig. 4). It generally shows negative heteropycnosis at diakinesis (Fig. 4b), and is isopycnotic at metaphase I (Fig. 4d,e). At anaphase I the B chromosome divides equationally and hence at metaphase II it has only one chromatid (Fig. 4f). At anaphase II the B migrates to one pole independently of the $\mathrm{X}$ (Fig. $4 \mathrm{~g}, \mathrm{~h}$ ). In only one cell of specimen 15 was a B bivalent observed (Fig. 4c). As cells with B chromosomes are found near one another on the slide, it is highly probable that they came from the same cyst.

The frequency of B chromosomes is generally low (Table 3), except in one individual (16) in which the supernumerary is present in approximately 12 per cent

Table 2 Observed number of ring bivalents, rod bivalents and univalents compared with the random and non-random expectations

\begin{tabular}{|c|c|c|c|c|c|}
\hline \multirow{2}{*}{$\begin{array}{l}\text { Individual } \\
\text { number }\end{array}$} & \multirow[b]{2}{*}{$\mathrm{P}^{*}$} & \multicolumn{3}{|c|}{ Configurations } & \multirow[b]{2}{*}{ Probability } \\
\hline & & Ring II & Rod II & Univalents & \\
\hline 14 & 0.62 & $\begin{aligned} \text { O } & 467 \\
\text { R } & 735.74 \\
\text { NR } & 459.36\end{aligned}$ & $\begin{array}{r}1446 \\
901.89 \\
1454.64\end{array}$ & $\begin{array}{c}2 \\
552.76 \\
0\end{array}$ & $\begin{array}{l}0.00 \\
0.69\end{array}$ \\
\hline 4 & 0.52 & $\begin{array}{cc}\text { O } & 60 \\
\mathrm{R} & 391 \\
\mathrm{NR} & 57.84\end{array}$ & $\begin{array}{r}1384 \\
721.84 \\
1388.16\end{array}$ & $\begin{array}{c}4 \\
666.32 \\
0\end{array}$ & $\begin{array}{l}0.00 \\
0.81\end{array}$ \\
\hline 11 & 0.52 & $\begin{array}{cc}\mathrm{O} & 57 \\
\mathrm{R} & 356.93 \\
\mathrm{NR} & 52.80\end{array}$ & $\begin{array}{c}1254 \\
658.94 \\
1267.20\end{array}$ & $\begin{array}{c}18 \\
608.26 \\
0\end{array}$ & $\begin{array}{l}0.00 \\
0.53\end{array}$ \\
\hline 1 & 0.54 & $\begin{aligned} \text { O } & 139 \\
\text { R } & 395.41 \\
\text { NR } & 108.48\end{aligned}$ & $\begin{array}{c}1192 \\
673.66 \\
1247.52\end{array}$ & $\begin{array}{c}50 \\
573.86 \\
0\end{array}$ & $\begin{array}{l}0.00 \\
\approx 0\end{array}$ \\
\hline 15 & 0.51 & $\begin{array}{cc}\text { O } & 73 \\
\text { R } & 307.44 \\
\text { NR } & 23.64\end{array}$ & $\begin{array}{l}1062 \\
590.76 \\
1158.36\end{array}$ & $\begin{array}{c}94 \\
567.60 \\
0\end{array}$ & $\begin{array}{l}0.00 \\
\approx 0\end{array}$ \\
\hline
\end{tabular}

${ }^{*} \mathrm{P}=$ chiasma coefficient derived by dividing the average chiasma number per bivalent by the maximum number of chiasmata expected (Jackson, 1982, 1984). $\mathrm{O}=$ observed number, $\mathrm{R}=$ random, $\mathrm{NR}=$ non-random. 


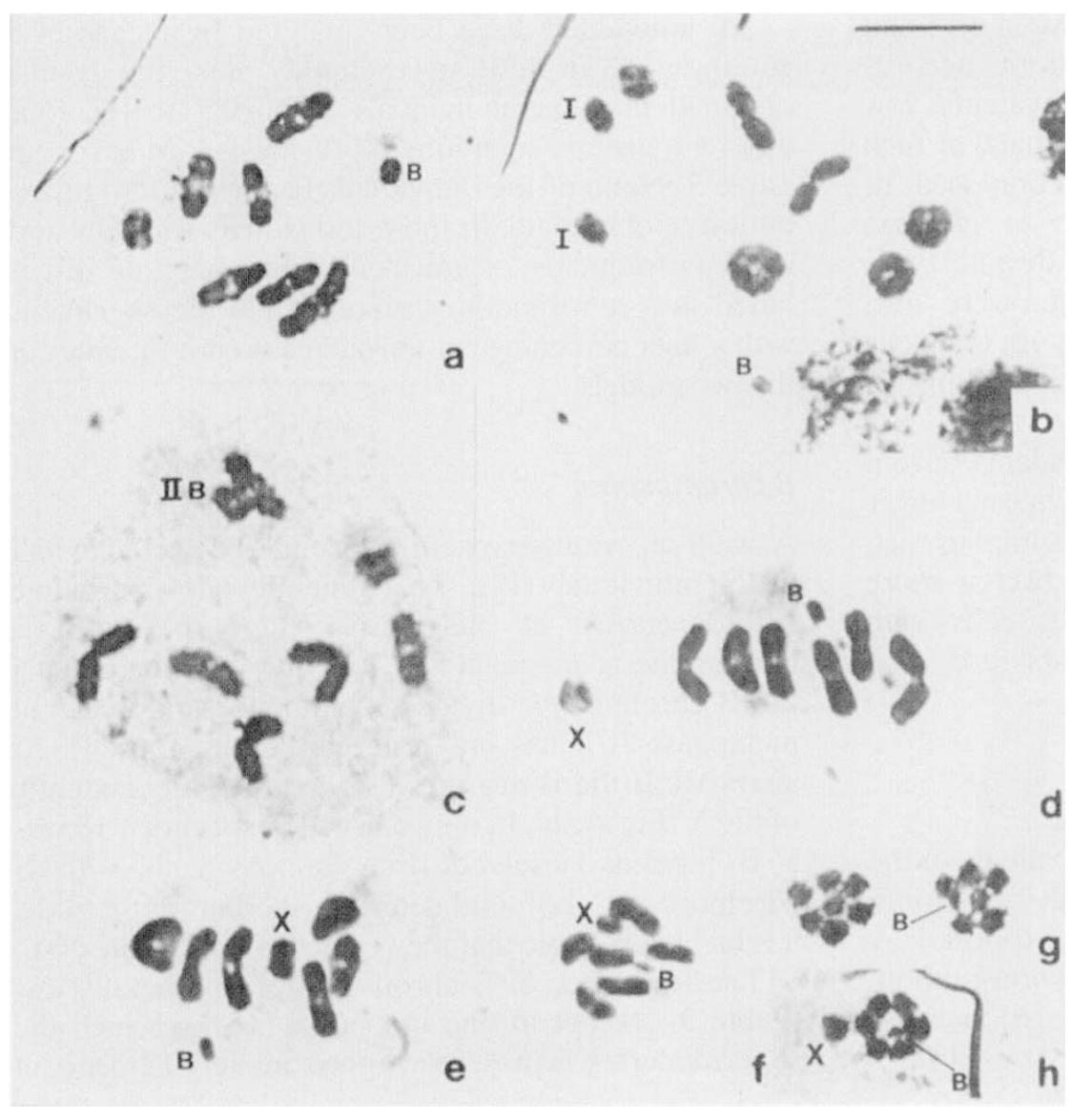

Fig. 4 Meiotic behaviour of B chromosome in L. rufipennis (Heteroptera). (a) Diakinesis with rod bivalents and B chromosome. (b) Diakinesis with three ring bivalents, two univalents and $B$ chromosome. (c) Diakinesis carrying a B bivalent. (d-e) Metaphase I. (f) Metaphase II. (g) Telophase II with $n=6 \mathrm{~A}+\mathrm{B}$ and $n=6 \mathrm{~A}+\mathrm{X}$. (h) Telophase II pole with $n=6 \mathrm{~A}+\mathrm{X}+\mathrm{B}$. Bar represents $10 \mu \mathrm{m}$.
Table 3 Percentage of cells with B chromosome

\begin{tabular}{|c|c|c|c|c|c|}
\hline \multirow{2}{*}{$\begin{array}{l}\text { Individual } \\
\text { number }\end{array}$} & \multicolumn{2}{|c|}{$\begin{array}{l}\text { Number of cells } \\
\text { at diakinesis-MI }\end{array}$} & \multicolumn{2}{|c|}{$\begin{array}{l}\text { Number of cells } \\
\text { at MII }\end{array}$} & \multirow{2}{*}{$\begin{array}{l}\text { Cells } \\
\text { with B (\%) }\end{array}$} \\
\hline & Total & With B & Total & With B & \\
\hline 9 & 303 & 1 & 134 & - & 0.23 \\
\hline 7 & 375 & 1 & 10 & - & 0.26 \\
\hline 8 & 320 & - & 38 & 1 & 0.28 \\
\hline 1 & 227 & 1 & 81 & - & 0.32 \\
\hline 2 & 283 & 2 & 89 & 1 & 0.81 \\
\hline 3 & 342 & 4 & 56 & - & 1.00 \\
\hline 5 & 201 & 4 & 86 & 1 & 1.74 \\
\hline 16 & 287 & 36 & 85 & 7 & 11.56 \\
\hline
\end{tabular}

$\mathrm{M}=$ metaphase.

of its cells. The regular meiotic behaviour of the B chromosome is confirmed in the latter by a chi-squared test, as B frequencies at metaphase I and II do not differ significantly $(P=0.28)$. Also in this individual, mean chiasma frequency in cells with $B$ is higher than in cells without the supernumerary (6.94 vs. 6.37) $(P=0.0075$, chi-squared test). In spite of this, a cell with ring bivalents together with two univalents and the B chromosome was detected (Fig. 4b).

\section{Discussion}

The first cytogenetic studies in the genus Largus were performed by Wilson (1909) who reported male and female diploid numbers of $L$. cinctus and $L$. succinctus. Fifty years later male meiosis of $L$. humilis (as Euryophthalmus humilis) was described by Piza (1953) and in recent years L. fasciatus (as E. fasciatus) has been cytogenetically described (Vidal \& Lacau, 1985); the latter two species share a diploid number of $12+\mathrm{XO}$ (male) with very large chromosomes.

Piza (1946) also made a thorough analysis of male meiosis in L. rufipennis (as E. rufipennis) from a sample of a Brazilian population. He pointed out the presence of V-shaped bivalents and up to four ring-shaped bivalents at diakinesis and prometaphase I, and explained them as the result of the presence of one chiasma in a terminal position and a telomeric association at the other chromosome ends. He did not even consider the possibility of the occurrence of two chiasmata and, 
under his hypothesis, interpreted the meiotic configurations as indicating that heteropteran chromosomes were dikinetic.

Our study in an Argentine population of $L$. rufipennis has also revealed the presence of up to four ring-shaped bivalents, but in this case the bivalents clearly show two terminal chiasmata. A remarkable difference between the two populations is the presence in the Argentine one of a B chromosome in some individuals and of a variable percentage of univalents in all of them. Considering the high number of individuals analysed by Piza ( 20 specimens) and the careful description he made, it is evident that these chromosome traits were absent in the Brazilian population.

As heteropteran chromosomes are telokinetic at meiosis, ring-shaped bivalents should have some difficulties in attaching to the spindle fibres. In a study on Nezara viridula $(2 n=12+\mathrm{XY})$ (Pentatomidae), Camacho et al. (1985) state that 'In holocentric systems ring bivalents are expected to separate as half rings at first anaphase. If this is indeed the case in Nezara, then presumably centric activity in ring bivalents must involve sites other than chromosome ends'. In $L$. rufipennis three kinds of bivalents are observed at prometaphase and metaphase I: rod bivalents, ring bivalents and V-shaped bivalents. According to our observations, bivalents with two chiasmata tend to be located at the periphery of the metaphase plate, a little apart from rod bivalents. While rod bivalents are axially orientated and firmly attached to the spindle fibres, ring bivalents are generally equatorially orientated and seem to be weakly attached. We propose that when one of the two chiasmata of a ring bivalent releases, one pair of telomeric regions is then free to attach to the spindle; the bivalent adopts a V-shape with the angle on the equatorial plane and open towards the centre of the plate (Fig. 1i, Fig. 2e, Fig. $4 \mathrm{~d}, \mathrm{e})$. It is capable of attaching firmly to the spindle fibres and at anaphase I this bivalent divides reductionally as the rod bivalents do. A similar situation has also been described in Belostoma oxyurum $(2 n=6+X Y)$ (Belostomatidae) (Papeschi, 1992).

\section{Univalents}

The appearance of univalents in all individuals poses some questions about their origin and consequences. As chromosome pairing seems to be normal, univalents are probably the result of a failure in chiasma formation (desynapsis).

The meiotic behaviour of the univalents in $L$. rufipennis is similar to that described in Acanonicus hahni (Coreidae, Heteroptera) (Papeschi \& Mola, 1990). They divide equationally at anaphase I, show touch-and-go pairing at metaphase II and segregate at anaphase II. In A. hahni each bivalent presents only one chiasma and therefore, a slight diminution in chiasma frequency necessarily causes the appearance of univalents. In L. rufipennis the situation is somewhat different because in this species bivalents with two chiasmata, together with univalents, are frequently observed.

\section{Chiasma frequency and distribution}

Two different situations regarding chiasma distribution have been proposed by Jackson $(1982,1984)$. According to his non-random model, each bivalent always presents at least one chiasma, and the other chiasmata are partitioned at random to bivalents that already have one. According to the author, normal diploid species have this type of chiasma distribution and the presence of univalents is rare and unpredictable. If chiasma distribution is of the random type, the appearance of cells with ring bivalents and univalents is expected in all individuals. In this case, Jackson (1984) suggests that univalents are the consequence of an alteration in distance relationships between nuclear attachment sites of homologous chromosomes (asynapsis). This situation has been encountered occasionally within species, and in some hybrids.

The individuals of $L$. rufipennis show a variable frequency of univalents; the comparison between the observed and expected frequencies under the random and non-random model of chiasma distribution revealed that individuals with a low and a medium frequency of univalents fit the non-random model. Jackson (1984) has already stated that desynaptic mutants may fit a non-random model. However, specimens with a high frequency of univalents do not follow either the non-random or the random models of chiasma distribution. In these individuals the percentage of cells with univalents is too high to be accepted under the non-random hypothesis, but not enough as to be considered the consequence of a random chiasma distribution. This indicates that the degree of desynapsis can be very variable.

\section{B chromosome}

Another irregularity detected is the presence of a $\mathrm{B}$ chromosome in half of the individuals (Table 3 ). In seven specimens the $B$ is present in less than 2 per cent of the cells, while in one individual it is present in approximately 12 per cent of the cells. This generally low frequency suggests that the supernumerary is mitotically unstable; as other tissues besides gonads have not been analysed, the presence of the $\mathrm{B}$ chromo- 
some in other individuals of the population cannot be discarded completely. On the other hand, the meiotic behaviour of the B chromosome is highly regular, and no tendency to its loss or accumulation has been detected; the only apparent effect is an increase in chiasma frequency in cells that carry the supernumerary.

According to Jones (1987) 'Chiasmata are extremely variable features of meiosis in terms of their number (frequencies), their distribution between cells and between bivalents, and their positional distribution along bivalents. The causes of chiasma variation are themselves variable and include genetic determinants and environmental causes, both internal and external to the organisms'. This variation is evident in the present population of $L$. rufipennis, where opposite forces are acting upon chiasma frequency: it is diminished by desynapsis and at the same time it is increased by the presence of a $\mathrm{B}$ chromosome. Besides, two individuals that lack $\mathrm{B}$ chromosomes also show a strikingly increased chiasma frequency. With the present information it is not possible to assess the influence of the genetic background and the internal and external environment on chiasma frequency and distribution. Although we suppose that the external conditions play a major role on chiasmata, further studies that consider both the population structure and the precise environmental variations are necessary.

\section{Acknowledgements}

We wish to thank Dr Axel Bachmann for taxonomic identification of the specimens. We are indebted to Dr L. Poggio for critical reading of the manuscript and her helpful comments. A.G.P. is a fellow of the Argentine Research Council (CONICET). This research was supported by grants to Dr J. H. Hunziker and Dr C. A. Naranjo from Consejo Nacional de Investigaciones Cientificas y Tecnicas (CONICET), Comision de Investigaciones Cientificas de la Provincia de Buenos Aires (CIC) and Universidad de Buenos Aires (UBA).

\section{References}

BANERJEE, M. K. 1959. Chromosome elimination during meiosis in the males of Macroceroea (Lohita) grandis
(Gray). Proc. Zool. Soc. (Calcutta), 12, 1-8 (cited by Manna, 1962).

CAMACHO, J. P. M., BELDA, J. AND CABRERo, J. 1985. Meiotic behaviour of the holocentric chromosomes of Nezara viridula (Insecta, Heteroptera) analysed by C-banding and silver impregnation. Can. J. Genet. Cytol., 27, 490-497.

JACKSON, R. C. 1982. Polyploidy and diploidy: new perspectives on chromosome pairing and its evolutionary implications. Am. J. Bot., 69, 1512-1523.

JACKSON, R. C. 1984. Chromosome pairing in species and hybrids. In: Grant, W. H. (ed.), Plant Biosystematics. Academic Press, London, pp. 67-86.

Jones, G. H. 1987. Chiasmata. In: Moens, P. B. (ed.), Meiosis. Academic Press, London, 213-244.

MANNA, G. K. 1984. Chromosomes in evolution in Heteroptera. In: Sharma, A. K. and Sharma, A. (eds), Chromosomes in Evolution of Eukaryotic Groups, vol. 2, CRC Press, Florida, pp. 189-225.

MANNA, G. K., UESHIMA, N., DEY, S. K. AND DEB-MALLICK, S. 1985. Marked sex chromosomal variations between Indian and Japanese species of Physopelta (Largidae, Heteroptera). Cytologia, 5, 621-630.

PAPESCHI, A. G. 1992. Estudios citogenéticos y evolutivos en Heteroptera. Tesis de Doctorado, FCEN, UBA.

PAPESCHI, A. G. AND MOLA, L. M. 1990. Meiotic studies in Acanonicus hahni (Stal) (Coreidae, Heteroptera). I. Behaviour of univalents in desynaptic individuals. Genetica, 80, 31-38.

PIZA, S. DE T. 1946. Comportamento dos cromossômios na meiose de Euryophthalmus rufipennis Laporte (Hemiptera, Pyrrhocoridae). Luiz de Queiroz, 3, 27-54.

PIZA, S. DE T. 1953. Provas cruciais da dicentricedade dos cromossômios dos Hemipteros. Luiz de Queiroz, 10, 156-186.

RAY-CHAUDHURI, S. P. AND MANNA, G. K. 1955. Evidence of a multiple sex chromosome mechanism in pyrrhocorid bug Physopelta schlanbuschi Fabr. Proc. Zool. Soc (Calcutta), 8, 65-77 (cited by Manna, 1962).

ueshima, N. 1979. Hemiptera II. Heteroptera. In: John, B. (ed.), Animal Cytogenetics, vol. 3. Insecta 6, Borntraeger, Berlin.

VIDAL, O. R. AND LACAU, I. M. 1985. Los cromosomas de Euryophthalmus fasciatus Blanchard (Heteroptera, Pyrrhocoridae). Physis (Buenos Aires), Sect. C, 43, 13-17. WHITE, M. J. D. 1973. Animal Cytology and Evolution, 3rd edn. Cambridge University Press, London.

WILson, E. B. 1909. Studies on chromosomes. IV. The accesory chromosomes in Syromastes and Pyrrhocoris, which a comparative review of the types of sexual differences of the chromosome groups. J. Exp. Zool., 6, 69-99. 